\title{
Proceeding
}

6th INSHS International Christmas Sport Scientific Conference, 11-14 December 2011. International Network of Sport and

Health Science. Szombathely, Hungary

\section{Motor and sports activities as a good means against of drug use}

\author{
PAVOL BARTÍK \\ Department of Physical Education and Sport, Faculty of Humanities, Matej Bel University, Slovakia
}

\begin{abstract}
Bartík P. Motor and sports activities as a good means against of drug use. J. Hum. Sport Exerc. Vol. 7, No. Proc1, pp. S147-S153, 2012. The author in his article solves the problems of drug dependence among young people and the problems of sport as a good means against drug dependence. The research sample consisted of 749 pupils of basic and secondary schools in the region of Banská Bystrica - 342 boys and 407 girls. The main research method was a questionnaire. The author found out that $54 \%$ of sportsmen and $37.75 \%$ of nonsportsmen said that sport is a good means against drug dependence. It is surprising that more than $25 \%$ of sportsmen did not know that sport could be a good means against drugs dependence. More than $44 \%$ of pupils said that they did not think that sportsmen do not take drugs. The author recommends putting more attention in drug prevention on education of young people in the family and also at schools. Key words: DRUG DEPENDENCE, PUPILS, SPORT.
\end{abstract}

Corresponding author. Department of Physical Education and Sport, Faculty of Humanities, Matej Bel University Tajovského street 40, 97401 Banská Bystrica, Slovakia.

E-mail: pavol.bartik@umb.sk

6th INSHS International Christmas Sport Scientific Conference, 11-14 December 2011. International Network of Sport and Health Science. Szombathely, Hungary

JOURNAL OF HUMAN SPORT \& EXERCISE ISSN 1988-5202

(c) Faculty of Education. University of Alicante

doi:10.4100/jhse.2012.7.Proc1.16 


\section{INTRODUCTION}

It is not a secret that the present state in drug use among the youth in Slovakia is alarming. Already some earlier enquiries in some regions in Slovakia revealed that every fourth of fifth secondary school student tried/tasted a soft or even a hard drug. To make the mater worse, also the number of primary school pupils who try drugs is increasing.

The Annual Report, which was published by the European Monitoring Centre for Drugs and Drug Addiction in Brussels in October 2002, says that in the years $1994-2000$ the use of drugs among young people in Slovakia was continually increasing. The same report states that while in the year 1995 only 25 percent of Slovak students considered marihuana an easily available drug, in the year 1999 the percentage increased to almost 48 per cent. Today almost 12 per cent of Slovak students are able to get the synthetic drug ecstasy, while in the year 1995 the number was lower than 8 per cent.

Today the problem of drug use in the youth in Slovakia is dealt with by a significant number of experts. On the basis of research they all state that the number of drug addicts is excessively high, every year it becomes higher and higher and the age limit of drug users is enormously decreasing. However, the research works on drug use in the youth mostly monitor the present state, but to a lesser extent they focus on prevention and ways of fight against drug abuse.

In scientific and research publications we can find a sufficient number of literary genres monitoring the present state of drug use in pupils and students at our schools. We can mention, for example, the works of Končeková (2001), Nagyová(1996), Ondrejkovič and Poliaková et al. (1999), Borošová and Bustínová (1996), Nociar (1996) and many others.

It is not possible to give a brief survey of such a great number of sources, and that is why we will mention at least some data. For example Nagyová (1996) questioned primary school pupils (2nd stage), students from secondary vocational schools, grammar schools and universities. The survey was carried out at selected schools in West Slovakia and Central Slovakia regions. She found out that, for example, at primary schools $5.9 \%$ pupils occasionally smoked, $28.1 \%$ pupils occasionally used alcohol, $5 \%$ pupils used alcohol regularly, $5 \%$ pupils tried drugs and $5 \%$ pupils used them regularly. The higher the age the higher the percentage of smokers and alcohol users, so that as many as $19.2 \%$ of university students smoked regularly and $23.5 \%$ occasionally. $10 \%$ students used alcohol regularly (which is only by $1 \%$ more than at secondary vocational schools and by $4.5 \%$ more than in grammar schools), however, as many as $77.2 \%$ of these students used alcohol occasionally. $29 \%$ of university respondents had a contact with another drug; however, the percentage of those who used a drug several times (10.5\%) is alarming. This is much higher than the percentage of students at grammar schools and secondary vocational schools. It is a pity that the author did not investigate and compare the occurrence of drug use in those pupils and students who went in for sports with those who did not do any sport.

Similarly striking results can be seen it the research of Končeková (2001). She questioned pupils at secondary vocational schools of services, construction and business in Košice $(n=346)$ and found out that $55.5 \%$ (58.6\% boys and $53.5 \%$ girls) of them sporadically smoked a cigarette. One quarter of the girls smoked occasionally and one quarter smoked every day, however, only approximately $10 \%$ boys smoked occasionally but almost $40 \%$ boys smoked every day. As many as $85 \%$ students $(83.5 \%$ boys and $85.9 \%)$ used alcohol (sporadically, occasionally or every day). These numbers are alarming; especially the 
percentage of girls is really high. $3.8 \%$ boys and $2.3 \%$ girls used alcohol every day, but as many as $70.9 \%$ girls had a drink sporadically or occasionally compared to $43.6 \%$ of boys.

Borošová and Bustínová (1996) carried out a survey in university students and found out some striking facts. In $78 \%$ of the respondents the use of alcohol increased in comparison with a secondary school. Moreover, $71 \%$ of university students would not like to be teetotallers. The main reason for that was that they did not want to be isolated from the society. Frequent alcohol drinking (more than twice a week) admitted $30 \%$ of university men students (but no women students).

$4.9 \%$ of the respondents (3.8\% of girls and $6.8 \%$ of boys) from secondary vocational schools (Končeková, 2001) used some other drugs (except alcohol and tobacco). Končeková (2001) states that these numbers are relatively low, because data in some other states, and even in some Slovak regions, are much higher. This fact is also in agreement with the findings obtained by Nagyová (1996). She says that $10 \%$ of secondary vocational school students used some other drugs occasionally and $5.6 \%$ regularly.

However, the survey of research works on drug use in students shows that their authors primarily monitor the structure and incidence of users or they try to determine the causes of this phenomenon and to a small extent they focus attention on prevention and the ways of fight against drug use. Maybe for this reason the published materials (with the exception of Nagyová, 1996) lack the topic of importance, opportunities and use of sports and recreational activities as one of the possible means in drug education.

Slepičková (1999) points to the co-existence of leisure time activities and drug use. She says that physical education and sport take up the first position in leisure time activities offered by school, however, the same as other leisure time activities, they do not concern a great part of students. As research shows, there is a considerable part of secondary school students (maybe a half) who do not have the opportunity to spend their free time in a proper way. And in connection with drugs this constitutes a great danger. She found out that sport decreases the risk of succumbing to drugs and other dependences. In secondary school students in the Czech Republic, about $30 \%$ of whom smoked, the occurrence of hard drug use made up $10 \%$ as early as 1998. It has been repeatedly shown that sport has an important influence on a lower occurrence of smoking and drinking. Those who do not do any sport show greater tolerance in their opinions about the harmfulness and social acceptability of drinking alcohol, and consume it at a larger amount.

Slepičková (2001) also presents another serious argument/fact; $23.6 \%$ of those secondary school students in whom sport belongs among three most favourite leisure time activities used a soft drug and $3.2 \%$ used a hard drug, while in the group of the respondents who did not include sport in their three most favourite activities $30.1 \%$ used a soft drug and $7.7 \%$ used a hard drug.

We could go on presenting excerpts and quotations about the use of sport as an antidrug barrier, but we think that the facts which we have presented so far are a sufficient argument in order to be able to accept sports and recreational activities as a significant part of leisure time activities which is advisable for young people in the fight against drug use and drug dependence. 


\section{MATERIAL AND METHODS}

The aim of our research was to find out the opinions of pupils and students of various age categories about drug dependence of schoolchildren in correlation with active sporting or sports passivity, to find out the occurrence of users of legal and illegal drugs in sporting and non-sporting school population, to compare the population in three age groups: $10-11$ years of age, $13-14$ years of age and $17-18$ years of age, and to draw conclusions from the data obtained. The research was carried out within the framework of the research target "Sports Activities as a Form of Specific Primary Prevention of Drug Dependence among Youth".

The basic method that we used was a questionnaire. The questionnaire contained 5 parts: anamnesis, physical education and sports activities of pupils, data about smoking, use of alcohol and drug use. The questionnaire comprised 50 questions, most of which were closed questions.

The enquiry was carried out at schools in the Region of Banská Bystrica.

342 boys and 407 girls submitted the questionnaires (Table 1). When analysing the questionnaire, we determined: frequency occurrence, percentage occurrence, correlations of questions and chi-square.

Table 1. Total structure of respondents.

\begin{tabular}{cccccccccc}
\hline $\begin{array}{c}\text { Age } \\
\text { category }\end{array}$ & $\begin{array}{c}\text { Total } \\
\text { number } \\
(\mathbf{n})\end{array}$ & \multicolumn{2}{c}{ Boys } & \multicolumn{2}{c}{ Girls } & \multicolumn{2}{c}{ City } & \multicolumn{2}{c}{ Countryside } \\
\hline & & $\mathrm{n}$ & $\%$ & $\mathrm{n}$ & $\%$ & $\mathrm{n}$ & $\%$ & $\mathrm{n}$ & $\%$ \\
\hline $10-11$ & 214 & 116 & 54.2 & 98 & 45.8 & 168 & 78.5 & 46 & 21.5 \\
$13-14$ & 227 & 117 & 51.5 & 110 & 48.5 & 223 & 98.2 & 4 & 1.8 \\
$17-18$ & 308 & 109 & 35.4 & 199 & 64.6 & 299 & 97.1 & 9 & 2.9 \\
\hline Total & $\mathbf{7 4 9}$ & $\mathbf{3 4 2}$ & $\mathbf{4 5 . 6 6}$ & $\mathbf{4 0 7}$ & $\mathbf{5 4 . 3 4}$ & $\mathbf{6 9 0}$ & $\mathbf{9 2 . 1 2}$ & $\mathbf{5 9}$ & $\mathbf{7 . 8 8}$ \\
\hline
\end{tabular}

\section{RESULTS}

Although the studies on leisure time activities and their use by young people often proclaim that sport can be considered an efficient means of the fight against drug use, it seems that pupils are not much aware of this fact - only less than a half of them expressed their agreement with this postulate. As much as one third of the pupils responded that they did not know that sport was a suitable means in the fight against drug use. This fact points to the need of a more intense action on the cognitive side of pupils. However, we can hypothesize that many pupils knew about various sports affairs with drug use in top sportsmen (and not only top sportsmen) in order to improve their performance or to kill pain. As a result of that, the respondents did not see only a positive function of sports activities and gave a negative a neutral answer to the question (Table 2). 
Table 2. Is sport an applicable means against drug use?

\begin{tabular}{ccccccccc}
\hline & \multicolumn{9}{c}{ Age categories } \\
\cline { 2 - 9 } Response & $\begin{array}{c}10-11 \text { years } \\
(n=214)\end{array}$ & \multicolumn{2}{c}{$\begin{array}{c}13-14 \text { years } \\
(n=227)\end{array}$} & \multicolumn{2}{c}{$\begin{array}{c}\text { 17-18 years } \\
(\mathrm{n}=308)\end{array}$} & \multicolumn{2}{c}{$\begin{array}{c}\text { TOTAL } \\
(\mathrm{n}=749)\end{array}$} \\
\cline { 2 - 10 } & $\mathrm{n}$ & $\%$ & $\mathrm{~N}$ & $\%$ & $\mathrm{n}$ & $\%$ & $\mathrm{n}$ & $\%$ \\
\hline Yes & 96 & 44.9 & 107 & 47.1 & 139 & 45.1 & 342 & 45.6 \\
No & 46 & 21.5 & 56 & 24.7 & 72 & 23.4 & 174 & 23.2 \\
I do not know & 72 & 33.6 & 64 & 28.2 & 97 & 31.5 & 233 & 31.2 \\
\hline
\end{tabular}

It is praiseworthy that in all three age categories of sporting pupils positive answers prevail and they are much higher (more than a half of the respondents) than those in non-sporting pupils. However, perplexing is the fact that one fifth of sporting pupils gave a negative answer and one quarter did not know that sport could be a good means against drug use.

In non-sporting respondents the percentage of positive answers is lower than in sporting respondents (more than one third), but higher is the percentage of answers that indicate that non-sporting respondents do not agree with the fact that sport is a good means against drug use, or they do not know about it.

When we considered including this question in the questionnaire, we expected more straightforward positive opinions of respondents about sport as an efficient means against drug use. These unexpected alarming results could be justified by two factors. Firstly, the respondents really lack knowledge of the positive side of sports activities, and secondly, the respondents they must have been influenced by the fact that many sportsmen succumbed to drugs (or used supporting mans), and they do not believe that sport could play a positive role in the fight against drug use. We can assume that they could acquire this knowledge from the news about top sportsmen and not recreational sportsmen. This means that we will have to take this fact into consideration when preparing a new questionnaire and make the diction more precise.

However, both the above-mentioned explanations of the quality of responses only accent the need for more intensive and more efficient public enlightenment and education at schools. A low percentage of positive responses to this question indicates that only a small number of the respondents are convinced that sporting pupils do not use drugs. It is necessary to think hard about this result and look for efficient ways of public enlightenment and educational campaign especially at schools. Also the responses to the previous question indicate that the ideas about the positive influence of sport on the life of youth do not conform to scientific knowledge and social and psychological experience. A high percentage of respondents who do not think that sporting pupils do not use drugs confirm this fact (Table 3). The highest percentage of those who think so is among $10-11$ year-old pupils, and this makes up one third In the other two age categories the numbers of those who agree are low both in the group of sporting and non-sporting pupils. A considerable number of respondents do not think that those pupils who do some sport do not use drugs. However, it is questionable to what extent the ideas of pupils could be confronted with reality, and also analogous to the previous question - what kind of drugs the respondents had in mind: whether just illegal drugs or also alcohol and tobacco. This could substantially change the view of the results. 
A great majority of the respondents gave a negative or uncertain (I do not know) answer to the question at the heading. The numbers of those respondents who are not sure are similar in all age categories of sporting and non-sporting pupils.

A surprisingly high percentage of $13-14$ year-old and $17-18$ year-old respondents - more than a half do not agree with the fact that pupils who do some sport do not use drugs. Even $17-18$ year-old sporting students gave as many as $59 \%$ of negative answers. This could indicate that they have better knowledge about sportsmen who use drugs than their younger schoolmates, and also that they may have more familiarly penetrated into sporting youth. However, this in no case casts a positive reflection upon sporting students, even if we included both legal and illegal drugs.

The responses to the question at the heading evoke the need to investigate pupils' opinions about their sporting schoolmates more closely. Also the questions that would bring knowledge of drug use in sporting youth could be formulated more precisely and in detail.

\section{DISCUSSION}

The respondents in all three age groups agree with the opinion that sport could be a good means against drug use. However, sporting pupils gave a higher percentage of positive answers (54\%) than non-sporting pupils (37.7\%). Similar findings have been reported in other studies (Slepičková, 2001; Končeková, 2001). In spite of this fact, the results are unsatisfactory. It is hard to believe that one fifth of sporting pupils gave negative answers and one quarter of sporting pupils did not know that sport could be a good means against drug use. Surprisingly few respondents thought that sport could be a good means in the fight against drug use (only $45.6 \%$ ), while one third of the whole sample did not know about the positive influence of sport and one fifth of the respondents even refused this fact. Pupils are not even convinced that their sporting schoolmates do not use drugs. As many as $44.7 \%$ of the pupils claim that they do not think that the pupils who go in for sport do not use drugs, and only $13.8 \%$ of the pupils think that sporting pupils do not use drugs.

In the groups of non-sporting pupils the negative responses are even more frequent than in the groups of sporting pupils. The highest percentage (one third) of the respondents who think that sporting pupils do not use drugs is in the group of $10-11$ year-old sporting respondents. In the other two age categories the numbers of positive answers in both sporting and non-sporting are much lower; in the group of $17-18$ ageold pupils it is only $8.1 \%$. The percentage of those who do not agree with this postulate is surprisingly high in both sporting and non-sporting pupils; in the category of $17-18$ year-old pupils we recorded even $59.4 \%$ of negative answers. Other authors have reported similar findings (Slepičková, 1999; Ondrejkovič and Poliaková et al. 1999).

\section{CONCLUSIONS}

We present the situation in preventation of drug use at basic and high schools. Further studies are required to construct models and programmes of sports activities suitable for pupils at schools during P.E. lessons and also at their leisure time as a good means against drug use. The very important is to develop the cooperation between family and school in preventation of drug use. 


\section{REFERENCES}

1. BOROŠOVÁ Z, BUSTÍNOVÁ L. Some aspects of using alcohol of University students. In: 4th International Congress CO-MAT-TECH. 1996; 121-123.

2. KONČEKOVÁ L. Drugs problems of pupils at schools. Prešov: Science, 2001.

3. NAGYOVÁ L. Drugs abuse of youth and leisure time. In: Olympic movement and Sports for all; 1996; 36-41.

4. NOCIAR A. The introduction to treatment of drugs abuse. Bratislava: Asklepios; 1996.

5. ONDREJKOVIČ P. \& POLIAKOVÁ E. The education against of drugs. Bratislava: Science; 1999.

6. SLEPIČKOVÁ J. Physical education and Sport in drugs preventation. Czech Kinanthropology. 1999; 3:57-64.

7. SLEPIČKOVÁ J. Sport and leisure time of students. Praha: UK; 2001. 